Wagner $\mathrm{H}$.

Historical and contemporary lessons of the transformation of Europe: the special case of GDR

Вагнер Г.

Тарихи және

қазіргі заманғы Еуропаның трансформациямануы: ГАР-дағы ерекше жағдай

Вагнер Г.

Исторические и современные уроки трансформации Европы: особый случай ГАР
In this article we consider the problem of the transformation of Eastern Europe on a special example of the GDR as «surprising opportunity». As can be judged from today's perspective, the self-dissolution of the German Democratic Republic (GDR) constitutes an obvious special case in the history of the transformation of the Central European and Central Asian states after the collapse of the Soviet Union. However GDR transformation is the exception to the rule. These aspects will be discussed in detail below. Owing to these particular circumstances, the political, economic and mental changes which ensued in the former GDR can hardly be compared with those in other transformation states. All that in my view can be compared is the extent of the economic decline of industrial production and the rise in unemployment in the "new German states» (the common term for the former territory of the GDR).

I will present a few typical facts about the far-reaching changes in the GDR, which saw the existing political, economic and ideological system abruptly and rigorously replaced but the mentality of the former GDR population hardly changed with regard to certain ideological attitudes. I will look at the transformees and transformers as well as at the winners and losers of GDR transformation and consider the lessons which can be drawn from this transformation, especially for individual nations and also for the international system of states as a whole, in particular for Eastern Europe and Central Asia.

Key words: History, Europe, Central Europe, Central Asia, transformation, GDR, international system, economy, ideology.

Осы мақалада біз Германия Аемократиялық Республикасын мысалға ала отырып, Шығыс Еуропаның трансформациялану мәселесін қарастырамыз. Орталық Еуропа мен бұрынғы Кеңес Одағында болған Орталық Азияның трансформациялануында ГАР-дың өзінөзі таратуы үлгі болды. Алайда, ГАР трансформациясы жалпы ережелерден ерекше дәрежеде болды деп қарастыруға болады. Бұл аспектілер төменде егжей-тегжейлі талқыланатын болады. Осыны нақты ескере отырып, бұрынғы Шығыс Германияда орын алған саяси, экономикалық және психологиялық (психикалық) өзгерістерді басқа мемлекеттерде болған өзгерістермен салыстыруға болмайды. Бұл жағдайда, менің ойымша, тек өнеркәсіптік өндірістің экономикалық баяулау Аәрежесі мен «жаңа неміс мемлекет» (ГАР бұрынғы аумағында қолданылған жалпы термин) аумағындағы жұмыссыздық, мәселесін салыстыруға болады.

Түйін сөздер: тарихы, Еуропа, Орталық Еуропа, Орталық Азия, трансформация, ГАР, халықаралық, жүйесі, экономика, идеология.

В Аанной статье мы рассматриваем проблему трансформации восточной части Европы на особом примере ГАР. Самороспуск Германской Аемократической Республики (ГАР) является, возможно, частным примером в истории трансформации государств Центральной Европы и Центральной Азии после распада Советского Союза. ОАнако трансформацию ГАР можно считать исключением из общих правил. Эти аспекты будут подробно обсуждаться ниже. В силу этих особых обстоятельств политические, экономические и психологические (ментальные) изменения, последовавшие в бывшей Восточной Германии, вряд ми можно сравнить с преобразованиями в Аругих государствах. Все, что, на мой взгляА, можно сравнить - это степень экономического спада промышленного производства и рост безработицы в «новом германском государстве» (общий термин Аля бывшей территории ГАР).

Ключевые слова: история, Европа, Центральная Европа, Центра^ьная Азия, трансформация, ГАР, международная система, экономика, илеология 


\section{HISTORICAL AND CONTEMPORARY LESSONS OF THE TRANSFORMATION OF EUROPE: THE SPECIAL CASE OF GDR}

\section{Introduction}

According to Helmut Wiesenthal, a «transformation» involves the restructuring of the whole society, a «complete system change» [1] which more or less affects all areas of society - the political, economic and also the ideological system of nations.

This means that «turning away from socialism» and a socialist system of state and «leaning towards capitalism» and a pluralist system must inevitably lead to far-reaching social change which, if it ensues at a forced pace, can certainly take on a revolutionary nature and have painful consequences.

In addition, the long-lasting mentality of a part of the GDR population can be compared with the fate of people in other nations socialized by «socialism». What is incomparable, and also unexpected, is the collapse of the Soviet imperium triggered by the loss of the GDR and the subsequent inexorable, groundbreaking development of the Central and Eastern European and Central Asian states, which initially was characterised by disintegration but later exhibited new forms of integration.

While other peoples managed to set up their own nation state, a stable democratic system and an operational market economy in a historical process lasting centuries, the GDR needed only to assume these through integration into the Federal Republic of Germany. Only now, two decades after the sudden begin of this process, is it gradually becoming apparent how much more difficult it would be for whole peoples largely left to cope alone with the completion of a „catch-up revolution» while carrying heavy historical baggage. Juergen Habermas argues that the current ,revolutionary changes» in Eastern Europe paved the way for „,catching up on neglected developments» [2]. By this he means that, by ,abolishing the people's democracies», the Eastern European countries sought to connect in constitutional terms with the legacy of the bourgeoisie revolutions and in terms of society with the forms of behaviour and lifestyles of developed capitalism, in particular of the European Community. The GDR however was only „catching up» on what for four decades had separated the western part of Germany from the eastern part: «the politically happier and economically more successful development». Habermas, profound and foreboding, adds that ,this char- 
acter of a catch-up revolution is confusing because it is reminiscent of the older use of language which had (apparently, H.W.) just been abandoned by the French Revolution - of the reformist sense of a return of political forms of rule which follow on from one another and replace each other like in the orbits of the stars» [3].

\section{The unexpected German reunification}

First of all, it must be taken on board that at the end of the 1980s almost no one in the Federal Republic of Germany believed that German reunification would happen any time soon. Back then the former Federal Chancellor Willy Brandt called the «talk of reunification» an «old lie of the German people», believing that it distracted people from embracing the two-state solution and making the best of it. Federal Chancellor Helmut Kohl once later confessed that, while he had always believed that German reunification would come, he didn't expect this to happen in his lifetime. The later Federal Chancellor Gerhard Schroeder declared as late as June 1989 that «after 40 years of the Federal Republic of Germany we shouldn't lie to another generation in Germany about the chances of reunification. There is no chance» [4]. This erring view is explained by the fact that at the time almost no one could imagine that the Soviet Union would give up the ghost as suddenly as it then did and be consigned willy nilly to the history books.

Positions on the domestic front. I cannot say to what extent US star journalist Bob Woodward's report in January 1990 is typical of the western perception of GDR-Germans' attitude. After a one-week stay in East Berlin, Woodward wrote in Time magazine that he had not met a single German who was in favour of unification. According to Woodward, no one there wanted a «capitalist GDR». As it would turn out shortly afterwards, he was completely wrong, having given credence to his left-wing East German informants, and perhaps also following his own prejudices. At the time of the article, in January 1990, a representative poll revealed that $76 \%$ of GDR inhabitants were in favour of the union of both states. On 18 March 1990 an overwhelming majority of the GDR population then voted for the GDR to be annexed by the Federal Republic of Germany as quickly as possible. The result was: $48.1 \%$ for the «Alliance for Germany», $21.8 \%$ for the SPD, $16.3 \%$ for the PDS, $5.3 \%$ for the «Union of Free Democrats» (FDP), and $2.9 \%$ for the "Alliance $90 »$, formed by GDR civil rights activists. All these parties, including the PDS, spoke out in favour of reunification as quickly as possible or at a later date [5].

In the first elections open to citizens in both states, on 2 December 1990, the only party which spoke out against a quick reunification was the West German Green Party, which received only 3.9\% support and thus, falling under the 5\% threshold, was no longer represented in the German parliament. Meanwhile, the Party of Democratic Socialism (PDS), which succeeded the Socialist Unity Party (SED) and which campaigned for unification, won $11.1 \%$ of the votes in the separate eastern electoral constituencies [5]. German reunification thus received impressive democratic legitimacy both from the GDR population and, after the GDR's selfdissolution of 23 August 1990 which was wrapped up on 3 October 1990, from the overall population of the new Federal Republic.

International reactions

When the opportunity for German reunification suddenly emerged on the political agenda in $1989 / 90$, the reaction of the four victorious powers from 1945 was different and far more complex than the attitude of the Germans. Initially only the US was in favour of reunification, and even then not without reservations but under the condition that the new Federal Republic in its entirety remained in NATO and the EU and that it recognized the existing borders in Europe, including the Oder-Neisse line between Germany and Poland. The British government under Margaret Thatcher was anything but enthusiastic, only being prepared to agree to changes to the existing European system of states with a united Germany at its centre after a long transitory period. French President François Mitterrand initially invested his hopes in Soviet General Secretary Mikhail Gorbachev, who he thought would prevent reunification. The overall election results were as follows: $\mathrm{CDU} / \mathrm{CSU}=43.8 \%, \mathrm{SPD}=33.5 \%$, $\mathrm{FDP}=11.0 \%$, PDS $=2.4 \%$, the $«$ Greens $»=3.9 \%$, the «Alliance 90», the combination of several east German opposition groups, $=1.2 \%$. The PDS and the «Alliance 90» were represented in the German parliament because they received more than $5 \%$ of the votes in the eastern electoral constituencies -9.9 and $5.9 \%$ respectively [6]. In this belief however Mitterrand was wrong.

Gorbachev swayed back and forth for a while. Speaking on 9 December 1989 before the Central Committee plenary of the Communist Party of the Soviet Union, he still brusquely rejected all plans for reunification. However, he changed his view in the course of the following month. On 30 January 1990 Gorbachev coolly informed a stunned GDR Prime 
Minister Hans Modrow, an SED bureaucrat of the old garde but with liberalist leanings and someone who continued to believe in the Soviet guarantees for the GDR's existence, that the Soviet Union's interests had changed and that it no longer considered the GDR as an interlocutor. On 10 February Gorbachev told Federal Chancellor Kohl that «the Germans themselves must resolve the issue of the unity of the German nation and decide in which state forms, at what time and with what speed and under what conditions they want to make this unity reality». The view of Philip Zelikow and Condoleezza Rice on the position of the Western powers on German reunification, was: "The Americans were the most benevolent in their behaviour, the French were more reticent, and Britain and the Netherlands were very standoffish» [7]. Ten years later he wrote in his memoirs that back then we «made it possible for the Germans to decide themselves». As desired by the Federal Government, when Gorbachev conceded on 16 July in Stavropol that the united Germany should encompass the Federal Republic, Berlin and the GDR and could also be a member of NATO and the EU. The ground was thus laid in the international arena for German reunification. After the fall of the Berlin Wall on 9 November 1989 had opened the door for reunification, it was then achieved step by step in the space of only 329 days, up to its final completion on 3 October 1990.

Thus, Germany was swift in taking the historic opportunity granted to it to make reunification happen. Under certain circumstances, a delay could have easily obstructed the whole project.

\section{Conditions for worldwide endorsement}

The difficult unification process, expertly staged and pushed by the US Administration under President George Bush senior and the Federal Government under Chancellor Kohl, was not only approved by the four directly involved victorious allies from 1945. At the EU's Strasbourg summit of 8-9 December 1989, all 12 member states at the time, including Britain, France and Italy, passed a declaration in principle endorsing Germany's unity as a state, although this «Strasbourg declaration» made no mention of this happening in the near future. Nevertheless, at the special Dublin summit four months later on 28 April 1990, the EU heads of state and government expressly welcomed the forthcoming reunification, expecting it to have a positive impact on the European integration process. German reunification also met with approval around the world.

One factor central to the largely positive response to German unity both on the domestic front and internationally was the Federal Republic's con- sent to recognize the Oder-Neisse line under international law and thus, for better or worse, to agree to the partition of one quarter of Germany's 1937 territory [8], and also its assurance that it would remain a NATO and EU member and actively support European integration. Chancellor Kohl endeavored to do just that up until the change of government in 1998. The GDR's accession to the Federal Republic and the EU on 3 October 1990 meant that its transformation had essentially become a task for the Federal Government.

\section{Aspects of the transformation process}

If GDR transformation is understood as total system change, then it is still not yet completed after a period of 25 years. The declared aim of GDR transformation was convergence with the Federal Republic, and this objective remains for the new German states to this day. They have achieved a pluralistic political system which corresponds to the rule of law and also an economic system which operates as a market economy, but with regard to political awareness there is still a considerable difference between "Ossis» and «Wessis», as the people from the two parts of the new Federal Republic were initially called. The reform of mentality appears to have ground to a halt. Even after 25 years there are marked differences between East and West Germans. It is perfectly possible that it will take a whole generation, another 30 years, to eliminate these differences.

\section{Innovation of the political system}

With regard to the political sector, three aspects of GDR transformation shall be examined more closely now, which bear witness to the changes that have ensued: the change of the constitutional order, the newly established party-political system, and the virtually complete replacement of the GDR's old political elite. The monopoly on power of a single party, the SED, has been broken. The monopoly of one party has been replaced by a pluralist multiparty system adhering to the norms of the reunified Germany's constitution. This constitution, which largely corresponds to the old Federal Republic's Basic Law of 1949, was adapted without much fuss to the new conditions of a united Germany through eight amendments under Article 72 of the Basic Law between 23 September 1990 and 26 October 1997. Article 146 Basic Law was originally worded: «This Basic Law loses its validity on the day a constitution enters into force which has been freely decided upon by the German people» [9].

As far as the party-political system in the new German states is concerned, the existence of 24 parties standing for election on 18 March 1990, 
of which 12 made it into the East German parliament, caused a certain amount of initial unrest on the domestic policy front. The Party of Democratic Socialism (PDS), this new party, which 15 years after the end of the GDR, in 2005, registered $8.7 \%$ nationwide and gained a party-record of $25.3 \%$ in East Germany when it ran under the name «Left Party/PDS» in the federal election [10], came to represent a specific group of voters which in eastern and western Germany is very different. With one exception, the PDS recorded consistently increasing results in the eastern electoral constituencies in earlier national elections: $9.9 \%$ in $1990,19.8 \%$ in $1994,21.6 \%$ in $1998,16.9 \%$ in 2002 [11]. I do believe that the «Left Party/PDS» can be considered to be democratic. This is confirmed by its participation in numerous coalitions at local council and local and regional government level. Therefore, in my view, it is wrong to flatly depict the party as anti- or undemocratic.

With the exception of the PDS, all parties in the new German states - both the Christian Democratic Union (CDU) and the Social Democratic Party of Germany (SPD), and also the liberal Free Democratic Party (FDP) and the Alliance 90 / Green Party - are entirely, or at any rate largely, «spin-offs» of the old Federal Republic parties which founded and funded them. It should be noted, however, that at least a certain tendency of all three phenomena plummeting membership levels among established parties, voter apathy and fluctuating voting preferences which can only be explained by populism can also be observed in the old German states.

Several facts very clearly demonstrate the rigour with which the personnel in the former GDR's government and civil service was reformed. Of the 8000 or so members of the diplomatic corps and foreign ministry of the GDR, just 35 interpreters were taken on by the external office of the Federal Republic of Germany.

\section{Discrepancies in German self-understanding}

What can be said about the opinions that East and West Germans have of themselves and of each other? To answer this question, I shall now present and comment on several findings from polls on five issues - the view of people in both parts of Germany: 1) on democracy; 2) on freedom and equality; 3 ) on socialism; 4) on the economic system in the old and in the new Federal Republic; and 5) on whether both parts will manage to grow together or not. As with all polls, the results should not be taken at face value. At best they illustrate trends of opinions and may, in some cases, demonstrate the continuity of convictions.
Over the past 14 years, the share of people who felt that democracy was the best form of government varied between $72 \%$ and $83 \%$ in western Germany, but between just $28 \%$ and $42 \%$ in eastern Germany. It is to be assumed that this discrepancy is the result of very different historical experiences. One characteristic which the statistics share is a slight downward trend, meaning that support for democracy has fallen equally in both parts of Germany.

The second question is, if somewhat more abstract, also concerned with the political views of people in both parts of Germany. Freedom and equality are rated very differently in eastern and western Germany. The eastern part favours equality, the western freedom. The opinions expressed in response to the third question of whether «socialism» is a «good idea» also share the same explanation - they are acquired through a specific process of socialization.

At first glance, the performance in the polls of the «social market economy», i.e. the economic system in the Federal Republic, is surprisingly poor. Wasn't it precisely this system that provided the West Germans with their «economic miracle» in the 1960s and the East Germans with an «explosion of prosperity» in the 1990s? [12] This crushing verdict, which saw support for the economic system of the recent past plunge to just $12 \%$ in the east and $25 \%$ in the west, can probably only be explained by seeing that the system is being held responsible for poor economic performance, horrendous unemployment and futile attempts to reduce social security expenditure.

It can be assumed, I think, that the $30 \%$ of east Germans in the polls - a relatively high proportion who would prefer it if two separate states continued to exist are not thinking of foregoing their prosperity but merely expressing their dissatisfaction at the circumstances in which the unity came about.

\section{Outcomes of transformation}

This is the place to draw an interim conclusion of the GDR's unique and almost impenetrable transformation process. What has been achieved, and what has not been successful? Obviously we are not talking about a final outcome, but rather a provisional result. My analysis has focused on just a few criteria. Of course, using other yardsticks leads to quite different verdicts. I have revealed my criteria - they are the facts which I consider to be important and which can be observed in the three sectors of society I have analyzed. They produce the following results in an analytical synopsis.

Political stability and integration through replacement of the elite and pluralization of the party landscape 
With regard to the political and constitutional sector, what I have neglected to portray is the lively constitutional debate which took place in the democratized GDR, admittedly only among a small group of mostly eastern and western intellectuals.

This debate however was inconsequential. As I described earlier, the Basic Law of the old Federal Republic was modified only slightly before becoming the constitution of the united Germany. With the best or worst will in the world, one cannot detect in it any particular sign of the GDR.

The party-political system in the new states was only briefly determined by a large number of parties. After the self-dissolution of the GDR, this number was soon reduced to just five parties, of which four were firmly established in the old Federal Republic: CDU, SPD, FDP and the Green Party, plus the PDS, which views itself as the democratized successor to the communist SED.

The fact that the leading politicians and administrators in the new states were not only largely removed, but replaced by top politicians and bureaucrats from western Germany as part of a huge «shopping spree» also made a fundamental contribution to the political stability of the Federal and state-level system of government. This defused the potential for conflict on the domestic policy front which existed in other transformation countries, where it frequently led to the disbandment's of individual parties and the creation of new ones, to volatile governments (i.e. frequent changes of government) and to low turnout in elections. The new states of Germany were certainly also spared these phenomena because the adoption of the Federal Republic's welfare state and the sustained increase in the standard of living softened the political conflicts. Nor has it prevented certain nostalgia for the GDR from becoming fashionable among particular sections of its former population.

Psychological consequences of socialization: less democratic but more egalitarian, economically predominantly pessimistic, but only slightly nostalgic

The antipathy towards the economic system in both the old and new Federal Republic is only gradually different, and emotional rather than fundamental in nature. Interestingly, there has evidently been a convergence of positions between the two sides on what the «idea of socialism» is.

All in all, I tend to interpret the collected data as actually showing a striking continuity of opinions and convictions in both eastern and western Germany. In spite of everything that has happened politically and economically in the 25 years since the end of the GDR, they have hardly changed, conserving a notable constancy. This is an indication of an «intellectual lag» in the former GDR, and equally in the former Federal Republic, at least with regard to the opinions revealed by the polls. Such attitudes are somewhat outdated! Admittedly, if Hegel was right when he said that Minerva's owl only takes flight in the evening, then that would seem to be true of attitudes in general. The quote: "If philosophy paints everything pessimistically, then a form of life has become old and the pessimism cannot be rejuvenated but only recognised; Minerva's owl only takes flight as darkness falls» [13]. Thinking always follow events.

Transformers and transformees, winners and losers of transformation

At the end of my analysis of and reflections on GDR transformation I would like to pose two questions which will lead me to the consequences of the transformation as mentioned in the title of this article. One question concerns the motives of the transformers and the reactions of the transformees, and the other applies to the winners and losers of GDR transformation. Both questions are seldom posed, presumably because they are difficult to answer satisfactorily.

I shall ask them anyway, because they admit a host of answers.

I am reminded of what Claus Offe said about GDR transformation, back in 1992, so right at the outset, when it was only possible to speculate: This unique mode of transformation - probably the only politically acceptable one - which we can observe in the GDR (i.e. transformation per accession, H.W.) offers self-evident advantages in comparison with the mode of transformation in the other countries. These countries have to repair their ships on the open sea, while the GDR can be rebuilt in the dry dock of the Federal Republic.

The other countries have to rescue themselves, while for the new states there is a robust rescue crane at the ready. This external control over the transformation process goes hand in hand with specific drawbacks absent in other countries. As Wiesenthal has confirmed, «the GDR's special status should not be considered as invariably privileged», whereby Wiesenthal was rather understating [14].

All in all, everyone has been fortunate!

The East Germans - and not only them - have been fortunate in their misfortune, in that things have come to pass as they have. I think this becomes apparent when we try to uncover the winners and losers of the changes and transformations in the Eastern European and Central Asian countries. 
With regard to income and quality of life, all the others, particularly pensioners and the unemployed, but even those who lost dreams and jobs, can feel that they are winners. An additional aspect is that the first expansion of the EU to the East, to incorporate the GDR, was a forerunner for further enlargements, about which for a long time many Eastern and Western Europeans could only dream. And finally, German reunification in the EU framework resolved the apparently unsolvable «German question» quietly and almost without being noticed, even if it was painful for Germans for being connected with the loss of a quarter of their country's territory.

The solution to the intricate question, called the «German one» consisted of the fact, to my mind, that during the entire period of Germany's unity no mutually acceptable place could be found for Germany in a Europe split into sovereign states, because of the country's size and energy. Europe was always afraid of potential German hegemony, while Germany always feared being surrounded by potential enemies. Only in a united Europe, in which the former major powers were shackled or are at least about to sacrifice part of their sovereignty at the common altar (as hard as this is for them), could it be hoped that the always unstable European balance of power system could be overcome, once and for all.

As a result, everyone - the Germans and Europeans, and also the populations of the bordering Asian countries - can count themselves among the winners.

\section{Conclusion: comparing the incomparable}

I am nevertheless inclined to derive two general lessons from the transformation of the GDR and other Eastern European and Central Asian countries to date.

Firstly, it is desirable and in the general interest for two parts of a nation separated by force to freely unite and assist each other in the process of unification; as it is equally the right of nations united by force to separate from each other again in peace. Both these events have happened as a result of the transformation process in Central Europe and Cen- tral Asia. Secondly, the approval of the neighbours and the international community is necessary for such a national unification or divorce in order to be successful.

The common German transformation can serve as an example, in its impact if not its process, for a national unification which is not impossible even against a backdrop of conflicting political and economic systems, provided that the national will to unite and engage in mutual assistance has not been lost when unification becomes possible due to external circumstances. German history also teaches us however that this will can be lost over time. No one knows whether both German parts would have wanted reunification if the separation had endured for two more generations, as the example of Austria teaches us. It also seems certain to me that the neighboring countries would never have agreed to German reunification outside the framework of the EU and NATO. Those European states that have dissolved themselves in the course of their transformation and disintegrated into their national parts Czechoslovakia and Yugoslavia - can equally serve as examples. Somewhat belatedly they have demonstrated that multiethnic states fall apart if they do not, like Switzerland, grant minorities the same rights as the majority and give them space to unfold their own culture. It is also perfectly clear that both German unification and the Czechoslovakian and Yugoslavian separations were helped by extraordinary circumstances.

As the German case and also the recent history of the Eastern European countries have shown, it is therefore favourable, or even necessary, for nationbuilding and transformations of society of the type discussed here to receive external support and assistance if they are to succeed. It is even more advantageous if this aid is not only bilateral but multilateral or even supranational in nature. With a glance at the Central Asian countries, I will conclude by saying that small states will sooner or later fall victim to imperialist major powers, if they are isolated and do not receive backing and assistance from a community of states which guarantees through its form of organization that small nations within it are protected and their existence secured.

\section{References}

1 cf.: Helmut Wiesenthal (Ed.). Gelegenheit und Entscheidung - Policies und Politics erfolgreicher Transformationssteuerung (Opportunity and Decision - Policies and Politics for Successfully Steering Transformation). - Wiesbaden 2001. - P. $7 \mathrm{ff}$. Of the many books on transformation, I'll mention only four standard works here: Wolfgang Merkel. Systemtransformation - eine Einführung in die Empirie und Theorie der Transformationsforschung (System Transformations - Introduction to Empirical Studies 
and Theory of Transformation Research). - Opladen, 1999; Merkel W., Puhle H.-J. Von der Diktatur zur Demokratie - Transformationen, Erfolgsbedingungen, Entwicklungspfade (From Dictatorship to Democracy - Transformations, Conditions for Success, Development Paths). - Opladen, 1999; Wiesenthal H. Die Transformation der DDR - Verfahren und Resultate (GDR Transformation - Process and Outcomes). - Guetersloh, 1999.

2 Habermas J. Die nachholende Revolution (The Catch-Up Revolution). - Frankfurt a. - M., 1990. - P. 180.

3 ibid. - P. 181.

4 Schroeder K. Die veränderte Republik - Deutschland nach der Wiedervereinigung (The Changed Republic - Germany after Reunification). - Munich, 2006. - P. 104.

5 see: Goertemaker M. Die Berliner Republik. Wiedervereinigung und Neuorientierung. - be.bra Verlag. - Berlin, 2009.

6 Die deutsche Vereinigung - Dokumente zu Bürgerbewegung, Annäherung und Beitritt (German Reunification - Documents on Civic Movement, Approximation and Accession) / V. Gransow/K. H. Jarausch (Eds.). - Cologne 1991. - P. 244.

7 Sternstunde der Diplomatie - Die deutsche Einheit und das Ende der Spaltung Europas» (Fine Hour for Diplomacy - German Unity and the End of the Division of Europe), $2^{\text {nd }}$ edition. - Munich, 2001. - Pp. 165, 167ff.

8 Plato A. von. Die Vereinigung Deutschlands - Ein weltpolitisches Machtspiel (German Reunification - a Power Game in Global Politics), 2 ${ }^{\text {nd }}$ edition. - Berlin, 2003. - P. 274.

9 Bauer A., Jestaedt M. Das Grundgesetz im Wortlaut - Änderungsgesetze, Synopse, Textstufen und Vokabular zum Grundgesetz (The Wording of the Basic Law - Amendment Laws, Synopses, the Text at Certain Stages of History, and Vocabulary on the Basic Law). - Heidelberg, 1997. - P. 62-65.

10 Schroeder K., quoted above, p. 471.

11 Helmut Wiesenthal, quoted above, p. 74: with additional comments from me. The corresponding results for the PDS in the whole of Germany were: $1990=2.4 \%, 1994=4.4 \%, 1998=5.1 \%, 2002=4.0 \%$ and 2005 as „Left Party $/$ PDS» $=8.7 \%$.

12 Source: Allensbach Institute for Demoscopics, see: Schroeder K., quoted above, p. 751.

13 Hegel G. W. F. Collected Works. - Volume 7, $4^{\text {th }}$ edition of the jubilee edition. - Stuttgart-Bad Cannstatt, 1964. - P. $36 f$.

14 Claus Offe, quoted above, p. 260. The quote from Helmut Wiesenthal is from his article „Sturz in die Moderne - Der Sonderstatus der DDR in den Transformationsprozessen in Osteuropa» (Fall into the Modern - The Special Status of the GDR in the Transformation Processes in Eastern Europe), see: Michael Brie, Dieter Klein (Ed.), Zwischen den Zeiten (Between the Times). Hamburg, 1992. - P. 172. 